\title{
Engineering geological study of the Mai Khola Hyroelectric Project, Ilam, eastern Nepal
}

\author{
*Pusker Raj Joshi'1, Kamal Kant Acharya ${ }^{2}$, and Rabindra Dhakal ${ }^{3}$ \\ ${ }^{I}$ Solu Hydroelectric Project, Solukhumbu, Nepal \\ ${ }^{2}$ Central Department of Geology, Tribhuvan University, Kirtipur, Kathmandu, Nepal \\ ${ }^{3}$ Melamchi Water Supply Project, Sindupalchok, Nepal \\ *Corresponding author: geopusker2015@gmail.com
}

\begin{abstract}
The Mai Khola Hydroelectric Project, a run-of-river scheme, has a capacity $15.6 \mathrm{MW}$. It has design discharge of $16 \mathrm{~m}^{3} / \mathrm{s}$, design net head of $112.71 \mathrm{~m}$ and includes $2192 \mathrm{~m}$ long inverted-D shaped headrace tunnel with $4.3 \mathrm{~m}$ diameter, concrete dam of $10.6 \mathrm{~m}$ height and semi-surface powerhouse. The project area consists of rocks of the Middle Siwalik Subgroup, comprising of sandstone, siltstone and mudstone, interbedded frequently. Sandstone is predominant in headworks area, headrace tunnel and is completely absent in a surge tank, and penstock alignment. Siltstone alternating with thin layer of mudstone is predominant in powerhouse area. The headrace tunnel outlet portal and surge shaft lie on the hillslope characterized by colluvial deposits. The penstock alignment passes through highly weathered siltstone and mudstone. The semi-surface powerhouse and the tailrace canal lie on the lower alluvial terrace. The Main Boundary Thrust (MBT) is the major structure observed at about $90 \mathrm{~m}$ upstream from the weir axis. The average Q-value of rock mass along the headrace tunnel surface mapping was $0.062-1.33$ and after excavation the value was $0.004-0.23$. An extremely poor to poor relation was observed between the rock mass class on surface mapping and exceptionally poor to very poor on excavation. Analysing the results of the surface and underground study of the rock mass, the excess support is required during construction.
\end{abstract}

Keywords: Mai Khola Hydroelectric Project, Middle Siwaliks, Q-value, Tunnel, Rock mass

Paper Received: 16 Feb 2018

Paper Accepted: 16 May 2018

\section{INTRODUCTION}

Nepal has faced power crisis for several years in spite of abundant potentiality of hydropower. Up to few months back, there was load-shedding of up to 18 hours. Till now, the total installed capacity of hydropower in Nepal is about $784.49 \mathrm{MW}$ as reported by NEA (2016). However, this amount is very small in respect to its economically large potential (43000 MW). Government and many private sectors are active in the implementation and promotion of such projects. The Mai Khola Hydroelectric Project, run-of-river type scheme, has an installed capacity of $15.6 \mathrm{MW}$. The main feature of the project includes $10.6 \mathrm{~m}$ high concrete dam, $2192 \mathrm{~m}$ long headrace tunnel having inverted-D shaped, semi-surface powerhouse and $200 \mathrm{~m}$ long tailrace canal.

The project area is confined between $2647^{\prime} 00^{\prime \prime} \mathrm{N}$ and $2650^{\prime} 00^{\prime \prime} \mathrm{N}$ latitude, and $8752^{\prime} 30^{\prime \prime} \mathrm{E}$ and $8755^{\prime} 00^{\prime \prime} \mathrm{E}$ longitude. It is located at a distance of $30 \mathrm{~km}$ north from Birtamod in the East-West Highway (Fig. 1). The headworks of the project are located on the Mai Khola between the boarder of two Village Development Committees (VDCs) namely Chisapani and Soyak in the Ilam District. The right bank of the diversion dam lies in the Soyak VDC. The intake structures, inlet canal and settling basin are placed just downstream of the
Soktim Tea Garden and the headrace culvert (pressurized) is placed along the left bank of the river at the Gunmune Village of the Chisapani VDC. From Gunmune, headrace tunnel starts and runs across the hill passing the boarder of the Chisapani VDC and the Danabari VDC. The surge shaft area, penstock, power house, tailrace canal and outdoor switchyard are located in the Danabari VDC. The major hydraulic structures of the project are weir axis, intake, intake canal, spillway, headrace tunnel, surge shaft, powerhouse and tailrace canal which are located in the Middle Siwalik.

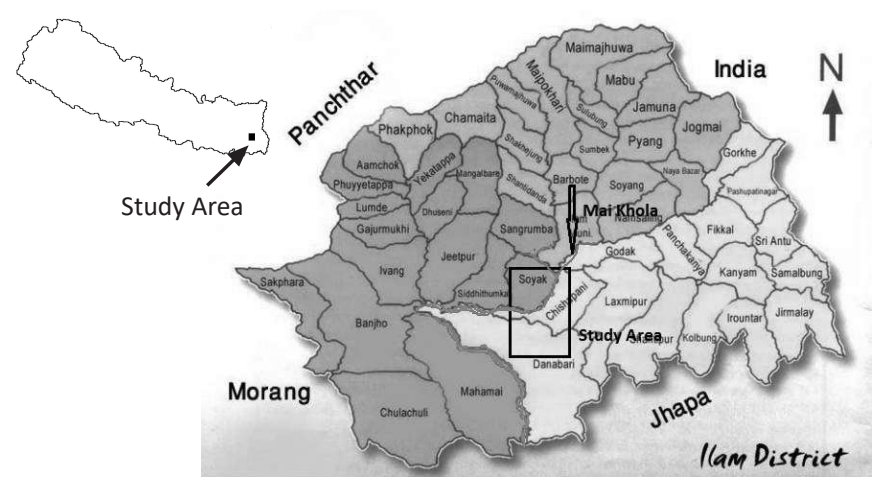

Fig.1: Location map of the study area 
The first aim of the study was to prepare geological map and cross-section, engineering geological map of headworks, surge shaft, penstock alignment and powerhouse area, and carry out the stereographic analysis of discontinuities and their interpretation. The second aim was to evaluate the support system along the tunnel alignment on the basis of Q (Barton et al., 1974) and RMR (Bieniawski, 1989) system and compare it with actually installed support system.

\section{Geology of the Project area}

The study area lies in the Middle Siwaliks (Figs. 2 and 3), according to the Geological map of Petroleum Exploration Block-10, Biratnagar, Eastern Nepal (after DMG, 1994), and is separated from the Lesser Himalaya by the Main Boundary Thrust at about $90 \mathrm{~m}$ upstream from the weir axis (Fig. 4). The MBT is characterized by about $2-3 \mathrm{~m}$ wide zone of alternate
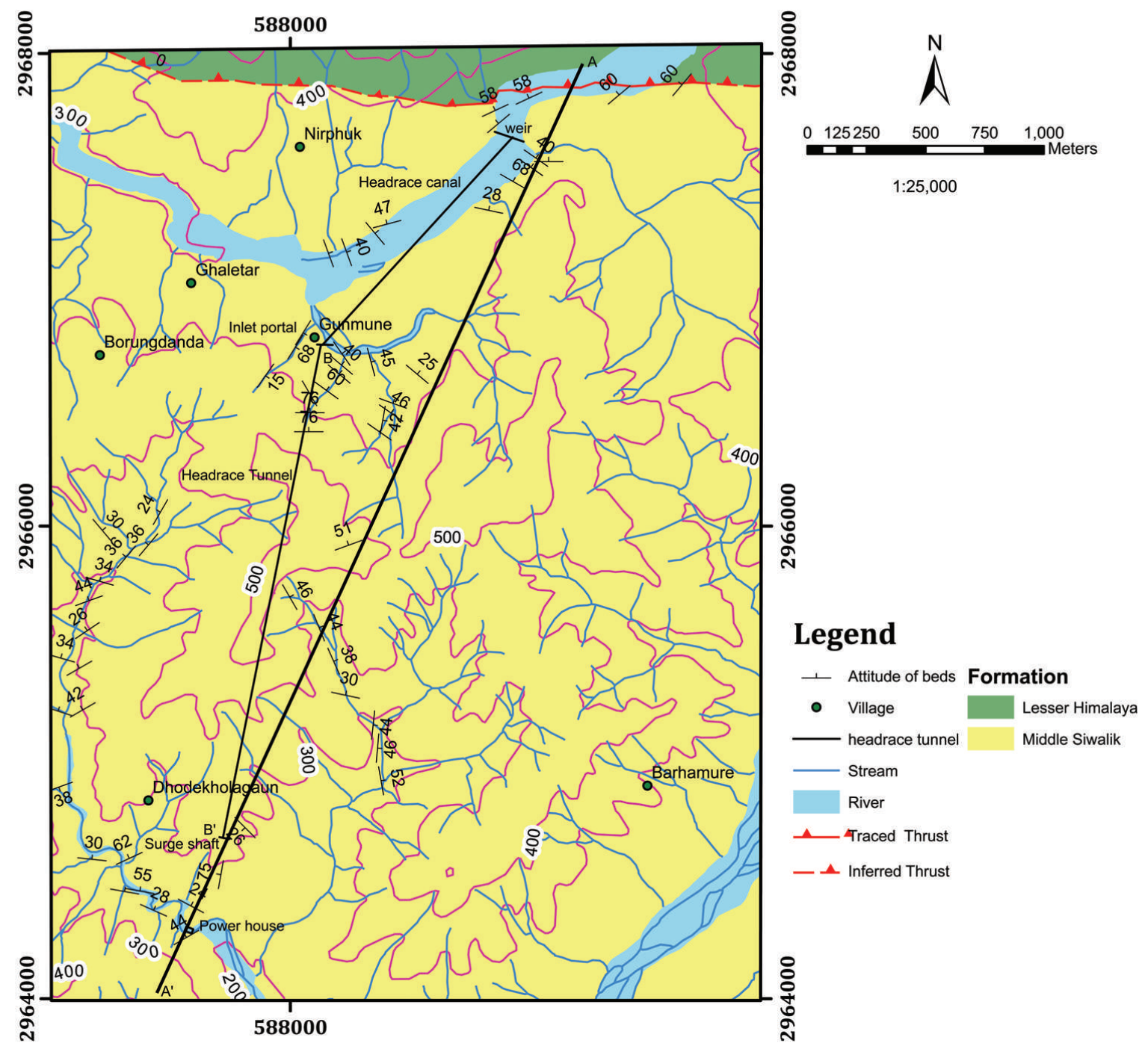

Fig. 2: Geological map of the study area, Ilam, Eastern Nepal

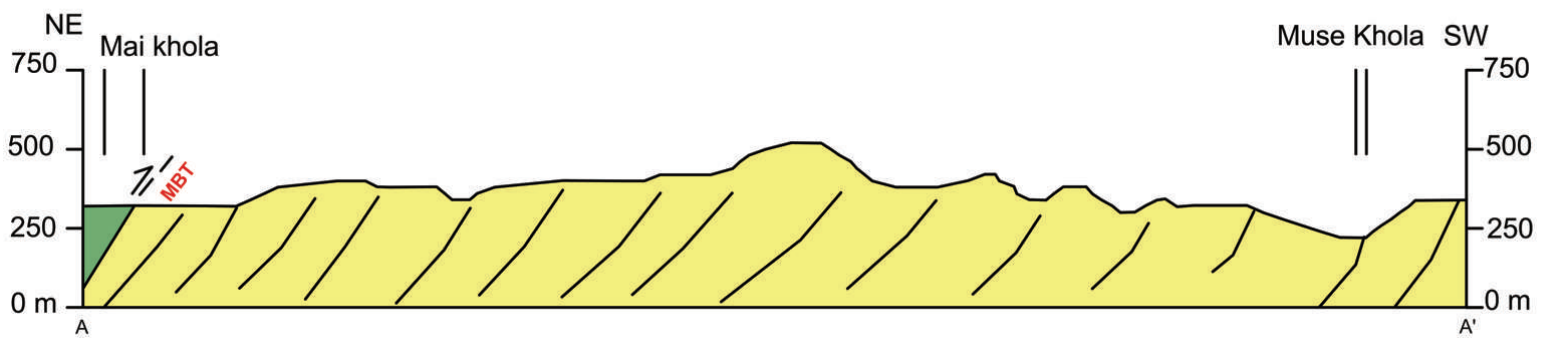

Fig. 3: Geological cross-section along the line A-A' 


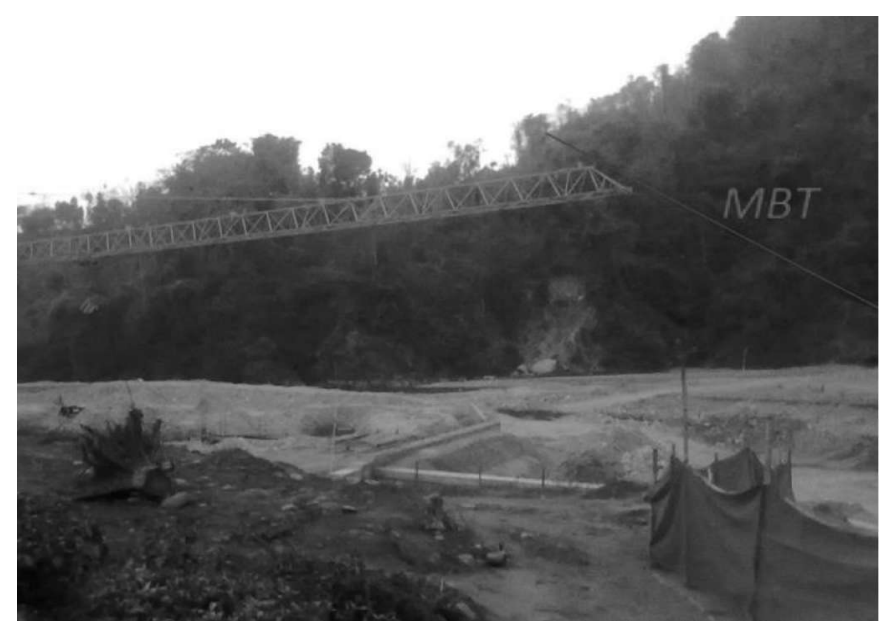

Fig. 4: Main Boundary Thrust near the Weir Axis

sheared/jointed rock and fault gauge/breccias. However, shearing effect was not observed in and around the proposed weir axis area. Hence, the effect of MBT is likely to be less in the weir site. The Middle Siwalik rocks consists of grey, medium- to coarse-grained, pepper and salt sandstone, and light bluish grey, medium-bedded, fine-grained siltstone and brownish grey mudstone. They are interbedded and repeated frequently. The bed rock distributed in headworks area is mainly pepper and salt sandstone and siltstone. The rock is slightly to moderately weathered, moderately strong, moderately to highly jointed and thinly to thickly bedded. Along the headrace tunnel, powerhouse and tailrace area, rock type consists of interbedding of sandstone and siltstone, and that of siltstone and mudstone. Many minor shear/weak zones of 5 to $10 \mathrm{~m}$ thick, which can be overcome by the necessary support, were identified along tunnel alignment. No other major structural disturbances were observed in the vicinity of the project.

In the geological map (Fig. 2), there are three lines AA', B-B' and the line drawn from the Wire Axis to the Inlet Portal. Geological cross-section along the line A-A' (Fig. 3) drawn from the Wire Axis to the Powerhouse Area provides geological information about the project area. The line B-B' drawn from the Inlet Portal to the Surge Shaft indicate the tunnel alignment and the line drawn from Weir axis to Inlet portal indicate Headrace Canal.

\section{ENGINEERING GEOLOGY OF THE STUDY AREA}

It included detailed engineering geological mapping of the major hydraulic structures of the project and rock mass classification of the headrace tunnel area with the stability analysis. Statistical joint analysis of the headrace tunnel has been done on the basis of the detailed measurement of all discontinuities. Rock tunneling quality index (Q) and RMR were used for the rock mass classification which helped to study the characteristics and quality of rock mass along the headrace tunnel and other structures.

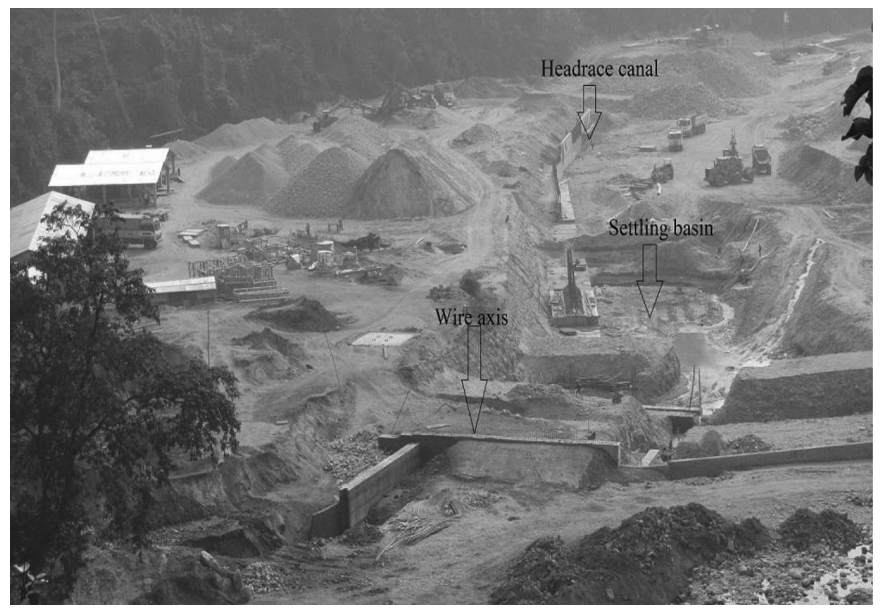

Fig. 5: Downstream view of Headworks site

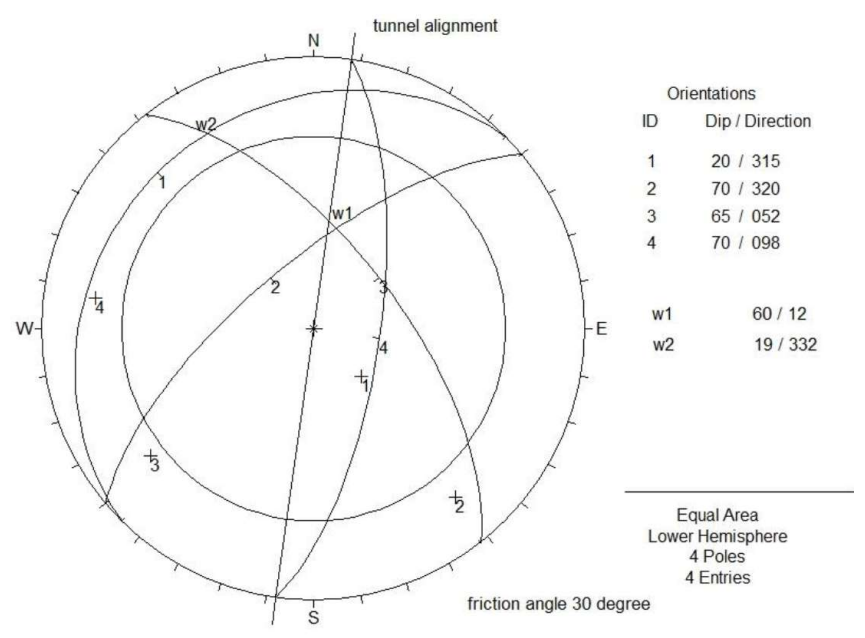

Fig. 6: Stereographic projection of discontinuities measured around the Weir Axis

\section{Headworks}

The headworks comprise the Weir Axis, Intake, Intake Canal, Settling Basin, Headrace Canal and the Inlet Portal. (Fig. 5). The Weir Axis is located on the Mai Khola at the Chisapani Area, where the river has an asymmetrical wide valley with gentle slope on the right bank. The Weir Axis is a permanent concrete structure. The arrangement has an effective length of about $86 \mathrm{~m}$ long free (uncontrolled) overflow weir having crest elevation at $320.60 \mathrm{~m}$ above mean sea level.

The natural hill slope at weir is 700 towards south east. The statistical analysis shows that there are three joint sets plus random (dip amount/dip direction) $\mathrm{J} 1: 70^{\circ} / 320^{\circ}, \mathrm{J} 2: 65^{\circ} / 52^{\circ}, \mathrm{J} 3$ : $20^{\circ} / 315^{\circ}$ and $\mathrm{J} 4: 70^{\circ} / 098^{\circ}$, respectively (Fig. 6). Two wedges $\mathrm{W} 1$ and W2 having trend/plunge $60^{\circ} / 12^{\circ}$ and $19^{\circ} / 332^{\circ}$. W1 is inside the friction circle (failure envelope) which is probable for failure during the excavation, whereas W2 is stable. 


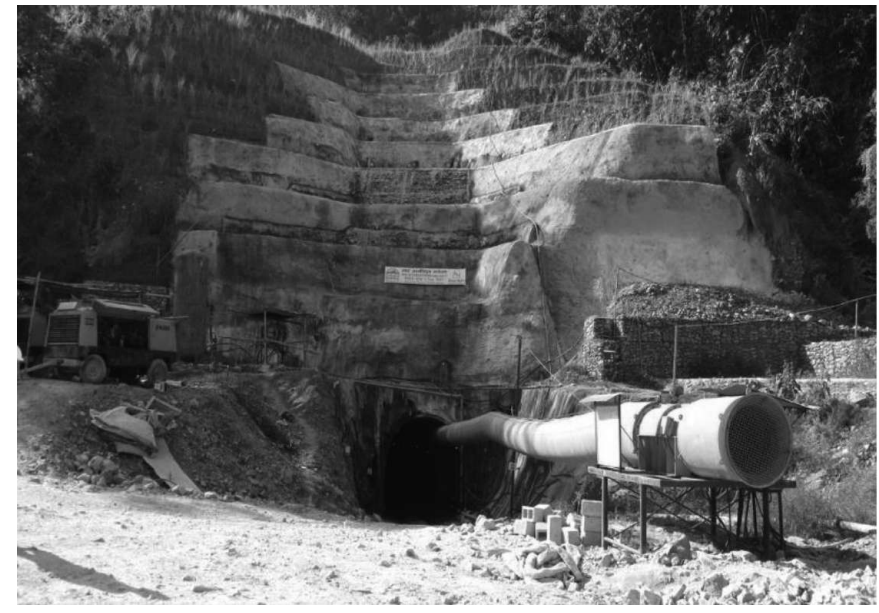

Fig. 7: Tunnel Inlet Portal of the Mai Khola HEP
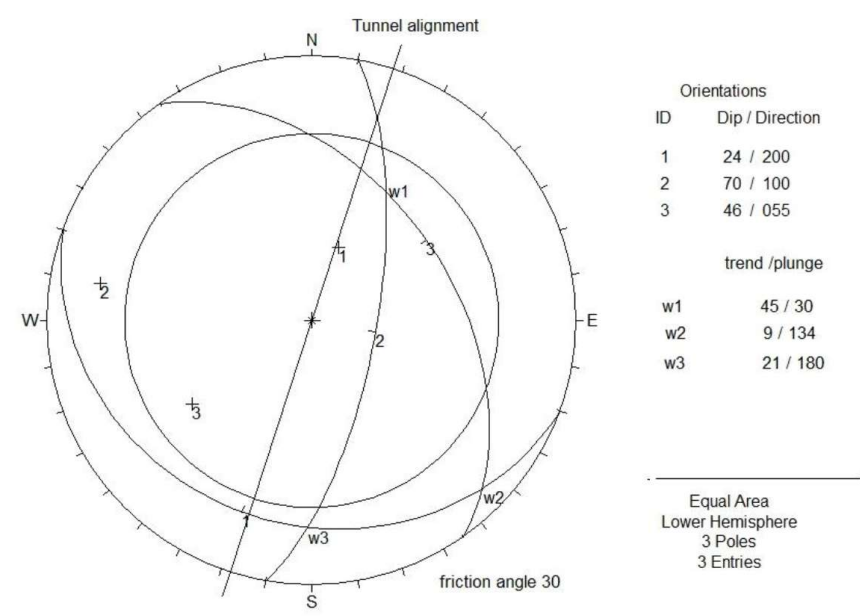

Fig. 8: Stereographic projection of discontinuities measured along the confluence of the Mai Khola and tributary near the Inlet Portal

The type of intake is frontal, submerged and over the undersulice. The intake arrangement has $6.0 \mathrm{~m}$ wide and 2.55 $\mathrm{m}$ clear slanted opening with sill elevation at $319.30 \mathrm{~m}$ above $\mathrm{msl}$. These openings are sufficient to withdraw design discharge of $16 \mathrm{~m}^{3} / \mathrm{s}$ and are furnished with coarse trash rack of $50 \mathrm{~mm}$ opening. The intake canal conveys flow to the settling basin. The type of intake canal is RCC open canal. The arrangement has spillways at the ends of riverside and hillside walls. Two numbers of surface settling basins, each with double chamber is designed to remove suspended particles before entering into the penstock. About $1072 \mathrm{~m}$ long canal conveys water from the settling basin to the headrace tunnel. The proposed headrace tunnel inlet portal is located on the left of the Mai Khola about $1072 \mathrm{~m}$ downstream from the weir axis (Fig.7). All these structures are in the alluvial terrace and flood plain. The detail engineering geological map of the headrace area and the Weir Axis are in Figs. 9 and 10.

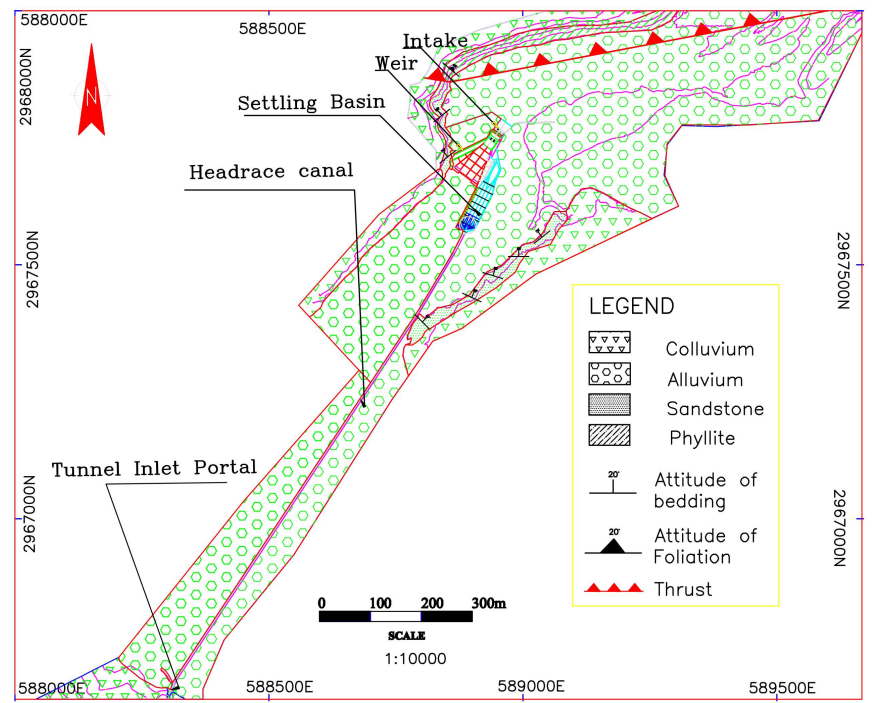

Fig. 9: Detail Engineering Geological Map of the Headworks area

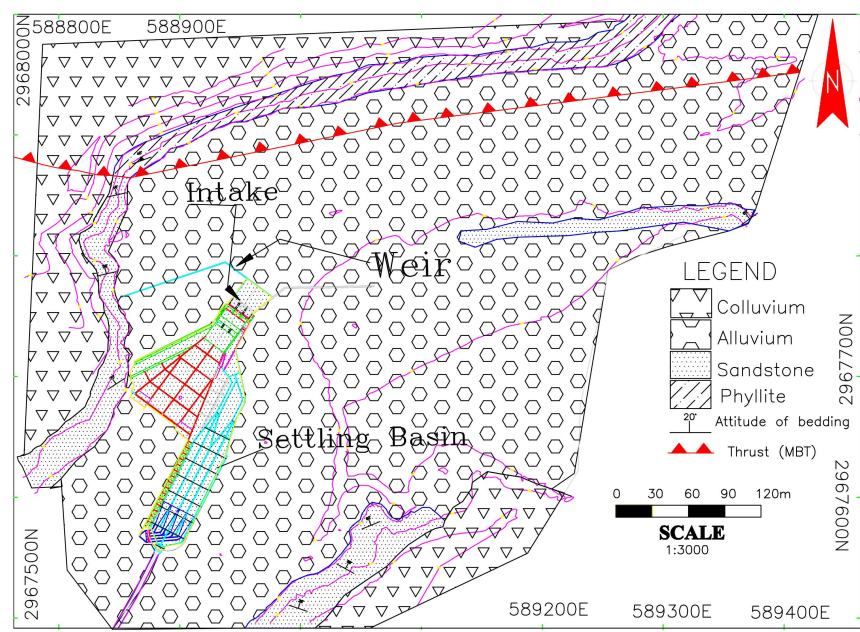

Fig. 10: Detail Engineering Geological Map of the wire axis

Along the confluence of the Mai Khola and the tributary near the Inlet Portal, the rock mass consists of three sets joints (dip amount/dip direction) $\mathrm{J} 1: 24^{\circ} / 200^{\circ}, \mathrm{J} 2: 70^{\circ} / 100^{\circ}$ and $\mathrm{J} 3$ : $46^{\circ} / 55^{\circ}$ (Fig. 8). There are three wedges formed. Wedge W1 is placed inside the friction circle so it is unstable and fall during excavation. $\mathrm{W} 2$ and $\mathrm{W} 3$ are at stable condition, since it is gentle then friction angle.

\section{Headrace Tunnel}

A proposed inverted-D shaped headrace tunnel of about $2126 \mathrm{~m}$ (2192 m including $66 \mathrm{~m}$ after surge-tank) long having an excavated diameter for shotcrete lined portion is $3.5 \mathrm{~m}$. The tunnel passes through the topography with medium relief. The entire tunnel crosses sandstone, siltstone and mudstone. The remaining little portion (about $4 \%$ ) is covered by minor shear zones. The maximum rock cover in the middle part is about 
$230 \mathrm{~m}$ at $0+560$ to $1+040 \mathrm{~m}$ chainage and the minimum rock cover is $15 \mathrm{~m}$ near the surge shaft area. Almost entire tunnel length passes nearly perpendicular to the strike of bedding plane which is favorable tunneling condition for the excavation drive with dip (i.e. drive from surge tank towards weir site). The rock mass present in entire tunnel alignment are repeatedly and cyclically occurring sandstone, siltstone and mudstone. However, several thin bands of weak zones represented by shear and fault zones are expected along the tunnel alignment. Those weak zones are categorized as poor to very poor rocks belong to rock class IV to V type. About $70 \%$ of the tunnel length is expected to be occupied by fair to good rock categorized as Class II and I type and the rest $26 \%$ is expected to be occupied by poor to very poor IV to $\mathrm{V}$ type. About $4 \%$ of total length of tunnel is expected to occupy by extremely poor rock. The majority of the tunnel length will be driven in fair to good rock thus the tunnel will be unlined for about $70 \%$ of its total length which will be only shotcrete lined with rock bolt. Only the $30 \%$ of the tunnel length will be concrete lined and steel ribs supported. It should be noticed that the geological condition along the tunnel alignment is mainly based on surface mapping and geological cross-section (Fig. 3). prepared along the headrace tunnel with tentative support pattern. The large section of tunnel passes through siltstone while the lesser section runs through sandstone. Shear bands are noticed in the tunnel zone mainly along the tributaries of the Muse Khola near powerhouse and near the Inlet Portal. The engineering geological condition of the headrace tunnel at different chainage is presented in Tables 1 and 2.

\section{Surge shaft /Penstock Alignment}

The surge shaft proposed at the end of the tunnel and immediately downstream of the rock trap is located at about $300 \mathrm{~m}$ upslope from the powerhouse area. The shaft consists of $8.0 \mathrm{~m}$ finished diameter with concrete lining of $0.6,0.4$ and $0.25 \mathrm{~m}$ thickness at lower, middle and upper part of the shaft, respectively. The penstock alignment passes along a ridge, which is situated at the left bank of the Muse Khola. The total length of the Penstock Tunnel is $316.38 \mathrm{~m}$ with a finished internal diameter of $2.35 \mathrm{~m}$. The surface geological mapping from surge tank to powerhouse indicates that the area above the alignment is mostly covered by colluvium and slope is about $50 \mathrm{o}$. The rock exposed in the penstock area is siltstone with presence of multiple shear bands. The Q-value and RMR estimated at rock outcrop are 0.015 and 38, respectively, and were categorized as extremely poor and poor-quality rock belonging to class VI and IV types. The strike of the rock is nearly parallel to the alignment of penstock and the orientation is unfavorable for the construction of penstock.

The stereographic projection of joints measured along the penstock alignment near the outlet portal The rock mass consists of three sets joints (dip amount/dip direction; Fig.11) $\mathrm{J} 1: 75^{\circ} / 280^{\circ}, \mathrm{J} 2: 54^{\circ} / 328^{\circ}$ and $\mathrm{J} 3: 44^{\circ} / 54^{\circ}$. There are three wedges formed. Wedge W2 and W3 are unstable so it falls during tunnel excavation. The W1 is at stable condition.

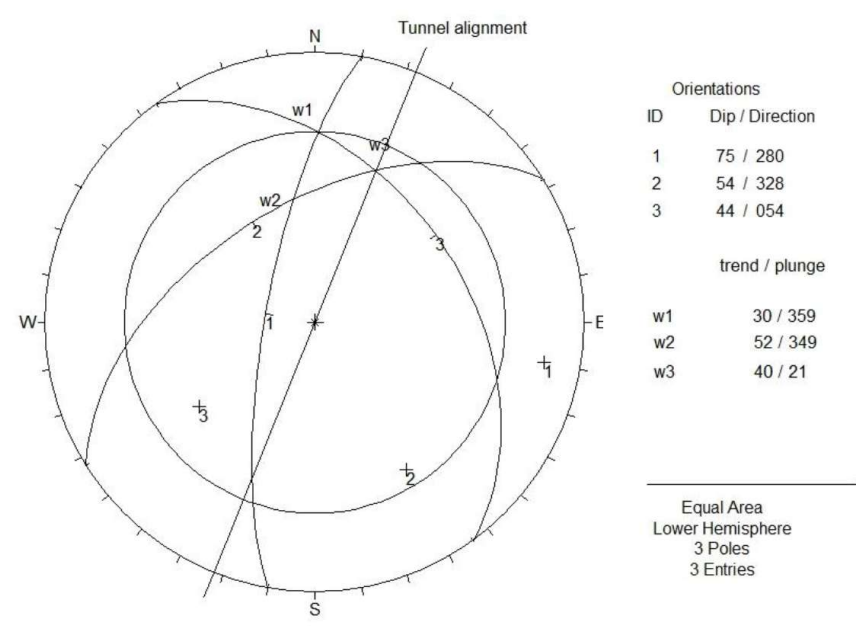

Fig.11: Stereographic projection of discontinuities measured along the penstock alignment near Outlet portal

\section{Powerhouse site}

The proposed powerhouse is located at the left bank of the Muse Khola about $300 \mathrm{~m}$ upstream of the confluence of the Muse Khola and the Dhode Kholsa (Fig. 12). The powerhouse is a semi surface structure to accommodate two generating units of capacity 7.8 MW each. The powerhouse site is composed of alluvial soil. The alluvial soil consists of dark grey, finedgrained, weak, semi-previous clayey sandy silt. The rocky outcrop on the hillslope at the powerhouse area consists of grey, highly jointed and crushed, moderately to highly weathered siltstone alternating with thin layer of mudstone. The attitude of bedding (dip amount/dip direction) is $42^{\circ} / 50^{\circ}$. Since the powerhouse is located in the flood plain and alluvium (Fig. 13) no any scheme of rock mass classification can be applied.

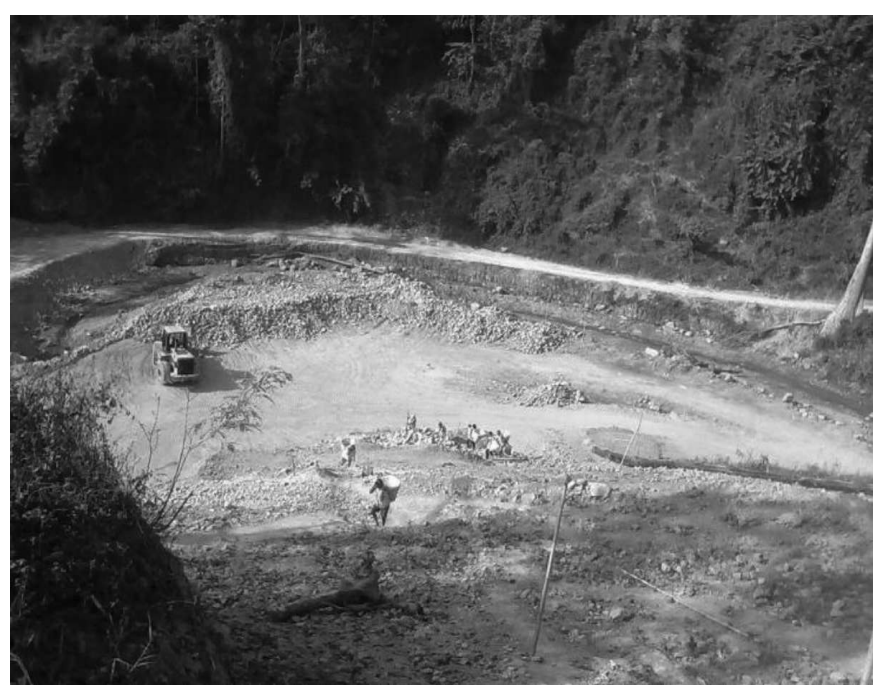

Fig. 12: Construction site of Power House of the Mai Khola HEP 


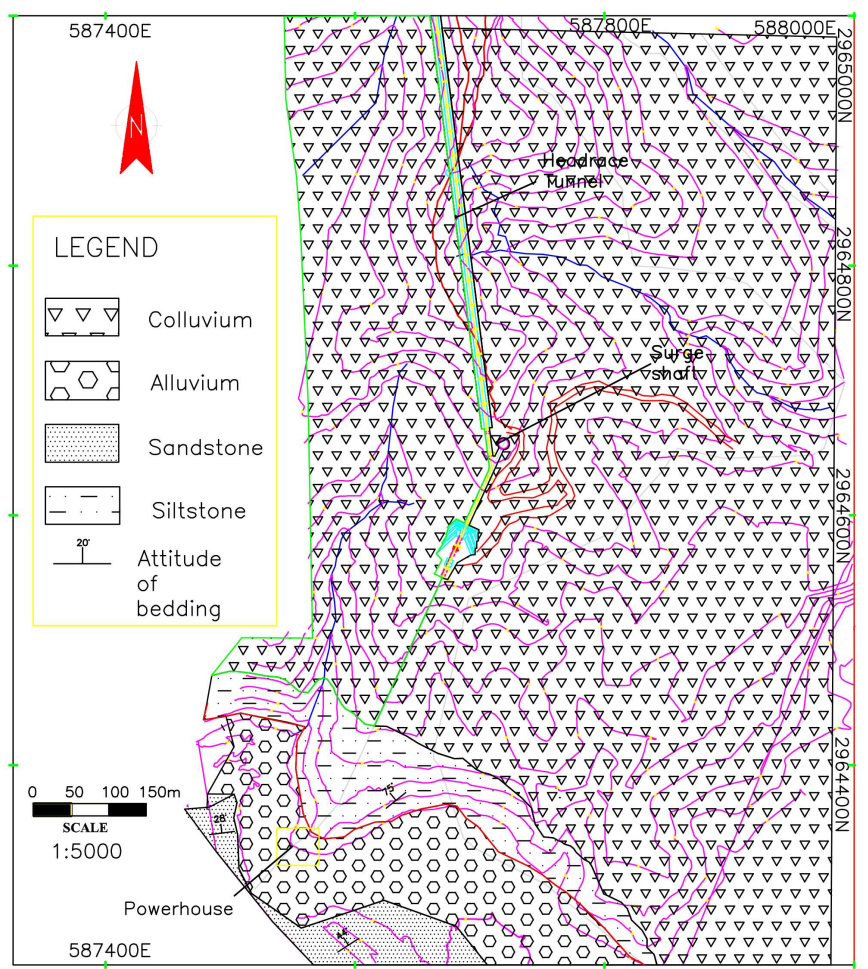

\section{Tailrace Structure}

The tailrace structure is proposed to run through the alluvial terrace along the right bank of the Muse Khola. The tailrace structure is fully concrete box culvert type. The structure needs erosion protection with boulders at the bottom and slopes creating a stable surface layer for flood discharge. The type of tailrace structure is RCC canal.

\section{SUPPORT ESTIMATION ALONG HEADRACE TUNNEL}

According to the Q and RMR system, estimation of rock support along tunnel alignment is in Table: 1 and Table: 2. In underground structure, the Tunneling Quality Index $(\mathrm{Q}$ system) is more effective and reliable than RMR system. It provides more accurate value than RMR system. RMR system is more reliable during surface mapping. The main reason behind using the two systems is to verify how the rock class and support system can change in same location point. Different Q values from the actual ground condition causing variation at different location points are indicated in Table 3 .

Fig. 13: Detail Engineering Geological Map of Powerhouse Area

Table 1: Table showing estimation of rock support based on $Q$

\begin{tabular}{|c|c|c|c|c|c|c|c|}
\hline Structure & Chainage & Rock type & $\mathrm{Q}$ value & $\begin{array}{l}\text { Rock } \\
\text { class }\end{array}$ & $\begin{array}{l}\text { Max. } \\
\text { unsupp- } \\
\text { orted } \\
\text { span } \\
\text { (m) }\end{array}$ & Rock bolts & Shotcrete \\
\hline \multirow{12}{*}{$\begin{array}{l}\text { Headrace } \\
\text { tunnel }\end{array}$} & $\begin{array}{l}0+000- \\
0+25 \mathrm{~m}\end{array}$ & $\begin{array}{l}\text { Siltstone and } \\
\text { Sand stone }\end{array}$ & 0.014 & VII & 0.58 & $\begin{array}{l}\text { Pattern bolting, } 2 \mathrm{~m} \text { long, bolt spacing } 1.7 \\
\mathrm{~m}-2.1 \mathrm{~m}\end{array}$ & $\begin{array}{l}\text { Fibre reinforced } \\
\text { shotcrete, } 120-150 \mathrm{~mm}\end{array}$ \\
\hline & $\begin{array}{l}0+25- \\
0+150 \mathrm{~m}\end{array}$ & $\begin{array}{l}\text { Sandstone } \\
\text { and Siltstone }\end{array}$ & 0.62 & IV & 2.64 & $\begin{array}{l}\text { Pattern bolting, } 2 \mathrm{~m} \text { long, bolt spacing } 1.0 \mathrm{~m} \\
-1.3 \mathrm{~m}\end{array}$ & $\begin{array}{l}40-100 \mathrm{~mm} \text { unreinforced } \\
\text { shotcrete }\end{array}$ \\
\hline & $\begin{array}{l}0+150- \\
0+280 \mathrm{~m}\end{array}$ & $\begin{array}{l}\text { Siltstone and } \\
\text { Sandstone }\end{array}$ & 0.062 & VI & 1.05 & $\begin{array}{l}\text { Pattern bolting, } 2 \mathrm{~m} \text { long, bolt spacing } 2.3 \\
\mathrm{~m}-2.5 \mathrm{~m}\end{array}$ & $\begin{array}{l}\text { Fibre reinforced } \\
\text { shotcrete, } 90-120 \mathrm{~mm}\end{array}$ \\
\hline & $\begin{array}{l}0+280- \\
0+410 \mathrm{~m}\end{array}$ & $\begin{array}{l}\text { Sandstone } \\
\text { and Siltstone }\end{array}$ & 0.613 & IV & 2.62 & $\begin{array}{l}\text { Pattern bolting, } 2 \mathrm{~m} \text { long, bolt spacing } 1.0 \\
\mathrm{~m} \text { to } 1.3 \mathrm{~m}\end{array}$ & $\begin{array}{l}40-100 \mathrm{~mm} \text { unreinforced } \\
\text { shotcrete }\end{array}$ \\
\hline & $\begin{array}{l}0+410- \\
0+540 \mathrm{~m}\end{array}$ & $\begin{array}{l}\text { Siltstone and } \\
\text { Sandstone }\end{array}$ & 0.016 & VII & 0.61 & $\begin{array}{l}\text { Pattern bolting, } 2 \mathrm{~m} \text { long, bolt spacing } 1.7 \\
\mathrm{~m}-2.1 \mathrm{~m}\end{array}$ & $\begin{array}{l}\text { Fibre reinforced } \\
\text { shotcrete, } 120-150 \mathrm{~mm}\end{array}$ \\
\hline & $\begin{array}{l}0+540- \\
0+820 \mathrm{~m}\end{array}$ & $\begin{array}{l}\text { Sandstone } \\
\text { and Siltstone }\end{array}$ & 0.63 & IV & 2.66 & $\begin{array}{l}\text { Pattern bolting, } 2 \mathrm{~m} \text { long, bolt spacing } 1.0 \\
\mathrm{~m}-1.3 \mathrm{~m}\end{array}$ & $\begin{array}{l}40-100 \mathrm{~mm} \text { unreinforced } \\
\text { shotcrete }\end{array}$ \\
\hline & $\begin{array}{l}0+820- \\
0+960 \mathrm{~m}\end{array}$ & $\begin{array}{l}\text { Siltstone and } \\
\text { Sandstone }\end{array}$ & 0.33 & $\mathrm{~V}$ & 2.05 & $\begin{array}{l}\text { Pattern bolting, } 2 \mathrm{~m} \text { long, bolt spacing } 1.0 \\
\mathrm{~m}\end{array}$ & $\begin{array}{l}\text { Fibre reinforced } \\
\text { shotcrete, } 50-90 \mathrm{~mm}\end{array}$ \\
\hline & $\begin{array}{l}0+960- \\
1+130 \mathrm{~m}\end{array}$ & $\begin{array}{l}\text { Sandstone } \\
\text { and Siltstone }\end{array}$ & 0.312 & $\mathrm{~V}$ & 2.0 & $\begin{array}{l}\text { Pattern bolting, } 2 \mathrm{~m} \text { long, bolt spacing } 1.0 \\
\mathrm{~m}\end{array}$ & $\begin{array}{l}\text { Fibre reinforced } \\
\text { shotcrete, } 50-90 \mathrm{~mm}\end{array}$ \\
\hline & $\begin{array}{l}1+130- \\
1+450 \mathrm{~m}\end{array}$ & $\begin{array}{l}\text { Siltstone and } \\
\text { Mudstone }\end{array}$ & 0.125 & VI & 1.39 & $\begin{array}{l}\text { Pattern bolting, } 2 \mathrm{~m} \text { long, bolt spacing } 2.3 \\
\mathrm{~m}-2.5 \mathrm{~m}\end{array}$ & $\begin{array}{l}\text { Fibre reinforced } \\
\text { shotcrete, } 90-120 \mathrm{~mm}\end{array}$ \\
\hline & $\begin{array}{l}1+450- \\
1+690 \mathrm{~m}\end{array}$ & $\begin{array}{l}\text { Sandstone } \\
\text { and Siltstone }\end{array}$ & 1.33 & IV & 3.58 & $\begin{array}{l}\text { Pattern bolting, } 2 \mathrm{~m} \text { long, bolt spacing } 1.3 \\
\mathrm{~m}-1.5 \mathrm{~m}\end{array}$ & $\begin{array}{l}40-100 \mathrm{~mm} \text { unreinforced } \\
\text { shotcrete }\end{array}$ \\
\hline & $\begin{array}{l}1+690- \\
2+126 \mathrm{~m}\end{array}$ & $\begin{array}{l}\text { Sandstone } \\
\text { Siltstone and } \\
\text { Mudstone }\end{array}$ & 1.32 & IV & 3.57 & $\begin{array}{l}\text { Pattern bolting, } 2 \mathrm{~m} \text { long, bolt spacing } 1.3 \\
\mathrm{~m}-1.5 \mathrm{~m}\end{array}$ & $\begin{array}{l}\text { 40-100 mm unreinforced } \\
\text { shotcrete }\end{array}$ \\
\hline & $\begin{array}{l}2+126- \\
2+192 \mathrm{~m}\end{array}$ & $\begin{array}{l}\text { Siltstone and } \\
\text { Mudstone }\end{array}$ & 0.0234 & VII & 0.71 & $\begin{array}{l}\text { Pattern bolting, } 2 \mathrm{~m} \text { long, bolt spacing } 2.3 \mathrm{~m} \\
-2.5 \mathrm{~m}\end{array}$ & $\begin{array}{l}\text { Fibre reinforced } \\
\text { shotcrete, } 120-150 \mathrm{~mm}\end{array}$ \\
\hline
\end{tabular}


Table 2: Rock mass classification along headrace tunnel based on RMR value

\begin{tabular}{|c|c|c|c|c|c|c|c|c|}
\hline Chainage & $\begin{array}{l}\text { Length } \\
\text { (m) }\end{array}$ & $\begin{array}{l}\text { Rock } \\
\text { type }\end{array}$ & $\begin{array}{l}\text { RMR } \\
\text { value }\end{array}$ & $\begin{array}{l}\text { Rock } \\
\text { class }\end{array}$ & $\begin{array}{c}\text { Rock } \\
\text { category }\end{array}$ & $\begin{array}{l}\text { Rock bolts ( } 20 \mathrm{~mm} \text { diameter } \\
\text { fully grouted) }\end{array}$ & Shotcrete & Steel rib \\
\hline $\begin{array}{c}0+000 \mathrm{~m}- \\
0+25 \mathrm{~m}\end{array}$ & $25 \mathrm{~m}$ & Siltstone & 46 & III & Fair & $\begin{array}{l}\text { Systematic bolts } 4 \mathrm{~m} \text { long } \\
\text { spaced } 1.5-2 \mathrm{~m} \text { in crown and } \\
\text { walls with wire mesh in crown. }\end{array}$ & $\begin{array}{l}50-100 \mathrm{~mm} \text { in } \\
\text { crown and } 30 \\
\mathrm{~mm} \text { in sides. }\end{array}$ & None \\
\hline $\begin{array}{l}0+25 \mathrm{~m}- \\
0+150 \mathrm{~m}\end{array}$ & $125 \mathrm{~m}$ & $\begin{array}{c}\text { Sandstone } \\
\text { and Siltstone }\end{array}$ & 55 & III & Fair & Same as above & Same as above & None \\
\hline $\begin{array}{l}0+150 \mathrm{~m}- \\
0+280 \mathrm{~m}\end{array}$ & $130 \mathrm{~m}$ & $\begin{array}{l}\text { Siltstone and } \\
\text { Sandstone }\end{array}$ & 46 & III & Fair & Same as above & Same as above & None \\
\hline $\begin{array}{l}0+280 \mathrm{~m}- \\
0+410 \mathrm{~m}\end{array}$ & $130 \mathrm{~m}$ & $\begin{array}{l}\text { Sandstone } \\
\text { and Siltstone }\end{array}$ & 50 & III & Fair & Same as above & Same as above & None \\
\hline $\begin{array}{l}0+410 \mathrm{~m}- \\
0+540 \mathrm{~m}\end{array}$ & $130 \mathrm{~m}$ & $\begin{array}{l}\text { Siltstone and } \\
\text { sandstone }\end{array}$ & 48 & III & Fair & Same as above & Same as above & None \\
\hline $\begin{array}{l}0+540 \mathrm{~m}- \\
0+820 \mathrm{~m}\end{array}$ & $280 \mathrm{~m}$ & $\begin{array}{l}\text { Sandstone } \\
\text { and siltstone }\end{array}$ & 50 & III & Fair & Same as above & Same as above & None \\
\hline $\begin{array}{l}0+820 \mathrm{~m}- \\
0+960 \mathrm{~m}\end{array}$ & $140 \mathrm{~m}$ & $\begin{array}{l}\text { Siltstone and } \\
\text { sandstone }\end{array}$ & 38 & IV & Poor & $\begin{array}{l}\text { Systematic bolts } 4-5 \mathrm{~m} \text { long, } \\
\text { spaced } 1-1.5 \mathrm{~m} \text { in crown and } \\
\text { walls with wire mesh. }\end{array}$ & $\begin{array}{l}100-150 \mathrm{~mm} \text { in } \\
\text { crown and } 100 \\
\mathrm{~mm} \text { in sides. }\end{array}$ & $\begin{array}{l}\text { Light to medium ribs } \\
\text { spaced } 1.5 \mathrm{~m} \text { where } \\
\text { required. }\end{array}$ \\
\hline $\begin{array}{l}0+960 \mathrm{~m}- \\
1+130 \mathrm{~m}\end{array}$ & $170 \mathrm{~m}$ & $\begin{array}{c}\text { Sandstone } \\
\text { and Siltstone }\end{array}$ & 53 & III & Fair & $\begin{array}{l}\text { Systematic bolts } 4 \mathrm{~m} \text { long } \\
\text { spaced } 1.5-2 \mathrm{~m} \text { in crown and } \\
\text { walls with wire mesh in crown. }\end{array}$ & $\begin{array}{l}50-100 \mathrm{~mm} \text { in } \\
\text { crown and } 30 \\
\mathrm{~mm} \text { in sides. }\end{array}$ & None \\
\hline $\begin{array}{l}1+130 \mathrm{~m}- \\
1+450 \mathrm{~m}\end{array}$ & $320 \mathrm{~m}$ & $\begin{array}{l}\text { Siltstone and } \\
\text { Mudstone }\end{array}$ & 45 & III & Fair & Same as above & Same as above & None \\
\hline $\begin{array}{l}1+450 \mathrm{~m}- \\
1+690 \mathrm{~m}\end{array}$ & $240 \mathrm{~m}$ & $\begin{array}{l}\text { Sandstone } \\
\text { and } \\
\text { Siltstone }\end{array}$ & 61 & II & Good & $\begin{array}{l}\text { Locally, bolts in crown } 3 \mathrm{~m} \\
\text { long, spaced } 2.5 \mathrm{~m} \text { with } \\
\text { occasional wire mesh }\end{array}$ & $\begin{array}{l}50 \mathrm{~mm} \text { in } \\
\text { Crown where } \\
\text { required. }\end{array}$ & None \\
\hline $\begin{array}{l}1+690 \mathrm{~m}- \\
2+126 \mathrm{~m}\end{array}$ & $436 \mathrm{~m}$ & $\begin{array}{l}\text { Sandstone } \\
\text { Siltstone and } \\
\text { Mudstone }\end{array}$ & 61 & II & Good & Same as above & Same as above & None \\
\hline $\begin{array}{l}2+126 \mathrm{~m}- \\
2+192 \mathrm{~m}\end{array}$ & $66 \mathrm{~m}$ & $\begin{array}{l}\text { Sandstone } \\
\text { Siltstone and } \\
\text { Mudstone }\end{array}$ & 38 & IV & Poor & $\begin{array}{l}\text { Systematic bolts } 4-5 \mathrm{~m} \text { long, } \\
\text { spaced } 1-1.5 \mathrm{~m} \text { in crown and } \\
\text { walls with wire mesh. }\end{array}$ & $\begin{array}{l}100-150 \mathrm{~mm} \text { in } \\
\text { crown and } 100 \\
\mathrm{~mm} \text { in sides. }\end{array}$ & $\begin{array}{l}\text { Light to medium ribs } \\
\text { spaced } 1.5 \mathrm{~m} \text { where } \\
\text { required. }\end{array}$ \\
\hline
\end{tabular}

\section{Installed support after excavation}

Depending on the Q system and the ground conditions encountered during the tunnel excavation, different support types are installed in the tunnel sections (Table 3 ). In initial sections (up to chainage $0+860 \mathrm{~m}$ and chainage $1+420 \mathrm{~m}$ to chainage $2+192 \mathrm{~m}$ of the Headrace Tunnel), the support systems used were II, III, IV, V and VI. Very poor to exceptionally poor rock mass were encountered. During the excavation of the Surge Shaft, extremely poor rock mass was encountered and the Vtype support was used. Similarly, in excavated section of the Penstock Tunnel, exceptionally poor rock mass was observed and therefore the VI-type support was used. III- and IV-type supports were frequently used in the Headrace Tunnel whereas the $\mathrm{V}$ type-support was occasionally used. At chainage $1+564.50$ $\mathrm{m}-1+576 \mathrm{~m}$ a fault plane separates the sandstone unit and the thinly bedded siltstone beds. At this zone Q-value was 0.2 and support type used was of V-type support.

\section{Comparison between Estimated Support and Actually Installed Support}

The Fig. 14 represents the difference between Q-value of headrace tunnel before and after excavation of the tunnel. The Q-value of headrace tunnel from surface mapping ranged from 0.014 to 1.33 (extremely poor). The Q-value for headrace tunnel after excavation ranged from 0.004 to 0.23 (exceptionally poor to very poor). In penstock tunnel the Q-value estimated was 0.0234 (extremely poor rock) whereas after excavation the observed Q-value ranged from 0.0057 to 0.023 (exceptionally poor to extremely poor).

The average Q-value of the Headrace Tunnel on surface mapping was 0.449 and after excavation the value was found to be 0.071 . Therefore, the difference of the Q-value came out to be $37.8 \%$ which indicates that excess support will be required after construction. 
Table 3: Q-value calculation

\begin{tabular}{|c|c|c|c|c|c|c|c|c|c|c|c|c|c|}
\hline $\mathrm{SN}$ & Parameter & $\begin{array}{l}\text { Ch: } \\
0+25 \\
\text { m }\end{array}$ & $\begin{array}{l}\text { Ch: } \\
0+150 \\
\mathrm{~m}\end{array}$ & $\begin{array}{l}\text { Ch: } \\
0+280 \\
\mathrm{~m}\end{array}$ & $\begin{array}{l}\text { Ch: } \\
0+410 \\
\mathrm{~m}\end{array}$ & $\begin{array}{l}\text { Ch: } \\
0+540 \\
\mathrm{~m}\end{array}$ & $\begin{array}{l}\text { Ch: } \\
0+820 \\
\text { m }\end{array}$ & $\begin{array}{l}\text { Ch: } \\
0+960 \\
\mathrm{~m}\end{array}$ & $\begin{array}{l}\text { Ch: } \\
1+130 \\
\text { m }\end{array}$ & $\begin{array}{l}\text { Ch: } \\
1+450 \\
\mathrm{~m}\end{array}$ & $\begin{array}{l}\text { Ch: } \\
1+690 \\
\text { m }\end{array}$ & $\begin{array}{l}\text { Ch: } \\
2+126 \\
\mathrm{~m}\end{array}$ & $\begin{array}{l}\text { Ch: } \\
2+192 \\
\text { m }\end{array}$ \\
\hline 1 & $\begin{array}{l}\text { Rock } \\
\text { Quality } \\
\text { Designation } \\
\text { (RQD) \% }\end{array}$ & 50 & 75 & 50 & 75 & 50 & 75 & 25 & 25 & 25 & 75 & 75 & 50 \\
\hline 2 & $\begin{array}{l}\text { Joint Sets } \\
\text { Number (Jn) }\end{array}$ & 12 & 12 & 12 & 12 & 12 & 12 & 12 & 12 & 12 & 9 & 9 & 9 \\
\hline 3 & $\begin{array}{l}\text { Joint } \\
\text { Roughness } \\
\text { Number (Jr) }\end{array}$ & 1.5 & 1.5 & 1.5 & 1.5 & 1.5 & 1.5 & 1.5 & 1.5 & 1.5 & 1.5 & 1 & 1.5 \\
\hline 4 & $\begin{array}{l}\text { Joint Water } \\
\text { Reduction } \\
(\mathrm{Jw})\end{array}$ & 1 & 1 & 1 & 1 & 1 & 1 & 1 & 1 & 1 & 1 & 1 & 1 \\
\hline 5 & $\begin{array}{l}\text { Joint } \\
\text { Alteration } \\
\text { Number (Ja) }\end{array}$ & 6 & 4 & 4 & 4 & 8 & 4 & 3 & 4 & 4 & 3 & 4 & 8 \\
\hline 6 & $\begin{array}{l}\text { Stress } \\
\text { Reduction } \\
\text { Factor (SRF) }\end{array}$ & 10 & 2.5 & 10 & 2.5 & 10 & 2.5 & 2.5 & 2.5 & 5 & 2.5 & 2.5 & 10 \\
\hline & $\begin{array}{l}\text { Total Q- } \\
\text { value }\end{array}$ & 0.014 & 0.62 & 0.062 & 0.613 & 0.016 & 0.63 & 0.33 & 0.312 & 0.125 & 1.33 & 1.32 & 0.0234 \\
\hline & Rock class & VII & IV & VI & IV & VII & IV & $\mathrm{V}$ & V & VI & IV & IV & VII \\
\hline
\end{tabular}

In this study area, mostly rock is weak siltstone and mudstone having thin joint spacing between them. Tunnel blasting mainly in soft rock creates high number of fracturs therefore causing number of joint sets to increase and since it is hard to identify the natural joints and artificial joints, RQD values assigned decrease resulting in poor rock mass quality. In surficial condition, moisture condition is lower than that in

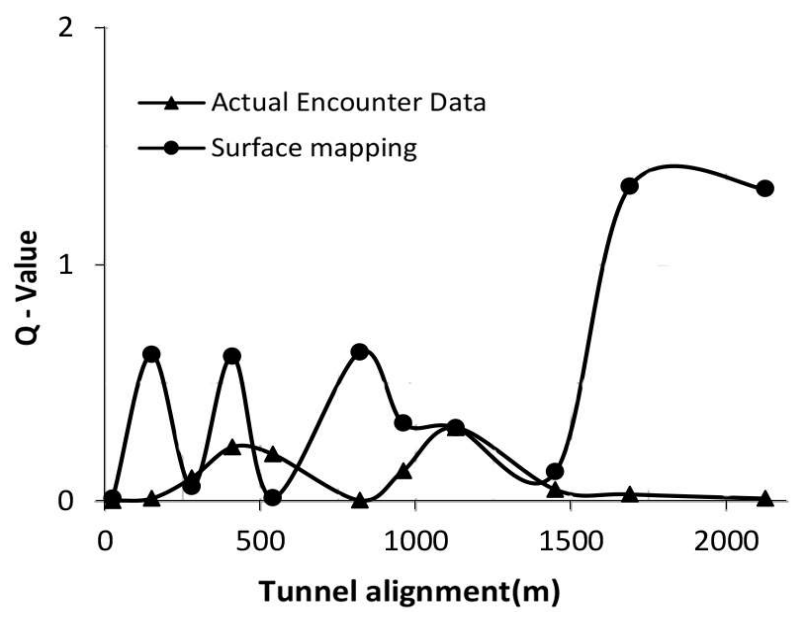

Fig.14: Distribution of Q-value along the headrace tunnel on surface mapping and after excavation the underground condition. The rock mass of the surface was dry to damp but inside the tunnel water was flowing, thus lowering the value of joint water reduction value ( $\mathrm{Jw})$. In surface mapping, the infilling inside rock wall was sandy with rock fragments but in the tunnel, infilling inside the rock wall is clay with micas. In surface mapping, rock surface was slightly rough to planar but inside the tunnel, rock surface was smooth planar thereby causing increase of the value of joint alteration number (Ja). In surface mapping, single weakness zone was found but during tunnel face mapping multiple occurrence of weakness zones was seen. Such multiple weak zones increases the value of stress reduction factor and causes lowering the Q-value.

When very little information about the rock mass is available during surface mapping it is not enough to predict the actual requirement of support during the tunneling stage. There is considerable difference observed in the estimation of support by surface mapping and installed support after excavation. The difference in excavated section of tunnel of $2192 \mathrm{~m}$, on rock class and support required is presented in Table 4. This comparison suggests that there requires bed by bed study of the tunnel alignment carefully during the surface study of the rock mass, for this we have to do further geophysical investigation such as ERT and Core drilling at different location point from headworks to powerhouse. Also, estimation of support is done by different methods which is useful to crosscheck each method and find out the error. 
Table: 4 Rock mass class and support required along the headrace tunnel on surface mapping and on excavation

\begin{tabular}{|c|c|c|c|c|c|}
\hline \multirow[t]{2}{*}{ Q-value } & \multirow[t]{2}{*}{ Rock Class } & \multirow[t]{2}{*}{ Rock Mass Description } & \multirow{2}{*}{$\begin{array}{l}\text { Support } \\
\text { Required }\end{array}$} & \multicolumn{2}{|c|}{ Length (m) } \\
\hline & & & & Surface & Excavation \\
\hline$>2$ & IV & Poor & I & 280 & 220 \\
\hline $0.6-2$ & IV, V & Very poor - Poor & II & $\begin{array}{l}960 \\
980\end{array}$ & 600,620 \\
\hline $0.2-0.6$ & $\mathrm{~V}$ & Very poor & III & 820 & 140 \\
\hline $0.04-0.2$ & $\mathrm{~V}, \mathrm{VI}$ & Extremely poor- Very poor & $\begin{array}{l}\text { IV(a) } \\
\text { IV(b) }\end{array}$ & $\begin{array}{l}1130 \\
1450\end{array}$ & 740 \\
\hline $0.01-0.04$ & VI & Extremely poor & V & 1000 & 60 \\
\hline$<0.01$ & VII & Exceptionally poor & VI & 25 & 40 \\
\hline Total & & & $1652 \mathrm{~m}(\mathrm{E}$ & section) & \\
\hline
\end{tabular}

\section{CONCLUSIONS}

Geologically, the Mai Khola HEP lies in the Siwaliks Zone in Eastern Nepal. In the study area, it comprises one unit: Middle Siwalik, consisting of grey sandstone, light bluish grey siltstone with thin layer of brownish grey mudstone. The Main Boundary Thrust is the major structures in the study area. The Q-value in the headrace tunnel is calculated as 0.014 to 1.33 . The average Q-value of rock mass along the headrace tunnel surface mapping is 0.449 and after excavation the value reduced to 0.071 . The average calculated Q-value in the penstock area is 0.0234 . Reduction in Q-values after the excavated conditions indicate need of excess support during construction.

When very little information about the rock mass is available during surface mapping it is not enough to predict the actual requirement of support during the tunneling stage. Use of more than one classification system assists in defining the characteristics of a rock mass to provide initial estimates of support requirements. After acquiring the relatively detailed information of rock mass properties, the use of rock mass classification schemes should be updated and used in conjunction with site specific analysis.

\section{ACKNOWLEDGEMENTS}

Authors thank Engineering Geologists Mr. Kapil Bhattarai and Mr. Surendra Shrestha from Himal Hydro and General Construction Ltd., and Engineering Geologists Mr. Sobit Thapaliya and Mr. Surya Limbu from Sanima Mai Hydropower Pvt. Ltd. for their kind helps during the field work. Authors are thankful to Mr. Lelin Raj Dhungel for assisting in the deskwork.

\section{REFERENCES}

Amatya, K. M. and Jnawali, B.M., 1994, Geological map of Nepal, scale: 1:10, 00,000 published by the department of Mines and Geology, Kathmandu, Nepal.

Barton, N., Lien, R., and Lunde, J., 1974, Engineering classification of rock masses for the design of rock support. Rock Mechanics, 6, pp. 189-236.

Bieniawski, Z.T., 1989, Engineering rock mass classifications: a complete manual for engineers and geologists in Mining, Civil, and Petroleum Engineering. A Wiley-Interscience Publication. John Wiley and Sons, New York. 251p.

Hoek, E. and Brown, E.T., 1980, Underground Excavation in Rock. The Institution of Mining and Metallurgy, London, $527 \mathrm{p}$. 
